\title{
Occult hepatitis B virus infection among injecting drug users in the Central-West Region of Brazil
}

\author{
Márcia Alves Dias de Matos ${ }^{1 /+}$, Renata Carneiro Ferreira ${ }^{1}$, \\ Fabiana Perez Rodrigues², Tamíris Augusto Marinho', Carmen Luci Rodrigues Lopes², \\ Antônia Carlos Magalhães Novais ${ }^{4}$, Ana Rita Coimbra Motta-Castro3 ${ }^{3}$, Sheila Araújo Teles², \\ Francisco José Dutra Souto ${ }^{4}$, Regina Maria Bringel Martins ${ }^{1}$
}

\author{
${ }^{1}$ Instituto de Patologia Tropical e Saúde Pública ${ }^{2}$ Faculdade de Enfermagem, Universidade Federal de Goiás, Goiânia, GO, Brasil \\ ${ }^{3}$ Departamento de Farmácia Bioquímica, Universidade Federal de Mato Grosso do Sul, Campo Grande, MS, Brasil \\ ${ }^{4}$ Faculdade de Ciências Médicas, Universidade Federal do Mato Grosso, Cuiabá, MT, Brasil
}

The prevalence of occult hepatitis B virus (HBV) infection was investigated in 149 hepatitis B surface antigen (HBsAg) negative injecting drug users (IDUs) in the Central-West Region of Brazil. Of these individuals, 19 were positive for HBV DNA, resulting in an occult HBV infection prevalence of 12.7\% (19/149); six of these 19 individuals had anti$H B V$ core and/or anti-HBV surface antibodies and 13 were negative for HBV markers. All IDUs with occult hepatitis $B$ reported sexual and/or parenteral risk behaviours. All HBV DNA-positive samples were successfully genotyped. Genotype D was the most common (17/19), followed by genotype A (2/19). These findings reveal a high prevalence of occult HBV infection and the predominance of genotype D among IDUs in Brazil's Central-West Region.

Key words: hepatitis B virus - occult infection - genotypes

Chronic hepatitis B virus (HBV) infection constitutes a significant public health problem that affects approximately 350 million individuals worldwide, despite the availability of a safe and effective vaccine (Liaw \& Chu 2009). The possible clinical outcomes of HBV infection include cirrhosis and the development of hepatocellular carcinoma (HCC) (Brechot et al. 2010). HBV is classified into eight genotypes (designated A-H) based on genomic sequence divergences of $\geq 8 \%$ (Kurbanov et al. 2010). Each of the genotypes has a typical geographical distribution; for example, genotypes A, D and F are the most prevalent in Brazil (Mello et al. 2007).

$\mathrm{HBV}$ infection is typically diagnosed based on the results of serological tests designed to detect the presence of the hepatitis B surface antigen (HBsAg) and the clearance of this antigen coincides with the disappearance of viraemia and disease remission. Occult HBV infection is characterised by the presence of HBV DNA in the blood and/or liver in HBsAg-negative individuals, who may present with or without antibodies to HBV core antigen (anti-HBc) and/or to HBsAg (anti-HBs) (Raimondo et al. 2007, Hollinger \& Sood 2010). Occult HBV infection is relevant in different clinical contexts. For example, carriers serve as sources for HBV transmission through blood transfusions or liver transplants. In addition, occult HBV infection may influence the progression of liver disease and HCC (Said 2011).

Financial support: $\mathrm{CNPq}$

+ Corresponding author: marciaalvesdias@yahoo.com.br

Received 30 April 2012

Accepted 8 August 2012
Injecting drug users (IDUs) are at increased risk for acquiring blood-borne infectious diseases, particularly HBV. HBV transmission in this population occurs through multiple pathways, including sexual transmission or exposure to contaminated blood through the sharing of needles, syringes or other injecting equipment (Alter 2003, Lugoboni et al. 2009). To date, few studies have documented the prevalence of occult HBV infection in IDUs (Torbenson et al. 2004, Lin et al. 2007, Trinks et al. 2008, Vitale et al. 2008). Furthermore, no data are available regarding occult $\mathrm{HBV}$ infection rates among IDUs in Brazil. Therefore, in this study, the prevalence of occult HBV infection was determined in the IDU population in the Central-West Region of Brazil. Risk behaviours and HBV genotypes were also identified.

Thousand and two individuals attending 34 public, private and charitable drug treatment centres in the capitals cities of three states (18 in Goiânia, state of Goiás, 8 in Campo Grande, state of Mato Grosso do Sul and 8 in Cuiabá, state of Mato Grosso) were recruited between August 2005-November 2006. Among these individuals, all IDUs $(\mathrm{n}=150)$ were selected for this cross-sectional study. Informed consent was obtained from all subjects. The participants were interviewed to collect data on sociodemographic characteristics, HBV-associated risk factors and previous HBV vaccination status. This study was approved by the Ethical Committee of the Maternal/ Infant Hospital in Goiânia.

Blood samples were collected and all serum samples were tested by ELISA for the presence of HBsAg (Hepanostika HBsAg Ultra, bioMérieux, Boxtel, The Netherlands), antibodies to the HBc (anti-HBc, Hepanostika anti-HBc Uni-form, bioMérieux) and antibodies to the HBsAg (anti-HBs, DiaSorin anti-HBs, Saluggia, Vercelli, Italy). In addition, tests were performed to 
detect anti-HCV (INNOTEST HCV Ab III, Innogenetics, Belgium) and anti-human immunodeficiency virus (HIV) antibodies by ELISA (Murex Biotech, UK). Anti$\mathrm{HCV}$ and anti-HIV-positive samples were retested using a line immunoassay (INNO-LIA HCV Ab III, Innogenetics) and Western blot analysis (BioRad Laboratories, France), respectively.

DNA was extracted from all IDUs' samples and the pre-S/S region was amplified using semi-nested polymerase chain reaction (PCR) as previously described (Niel et al. 1994, Motta-Castro et al. 2005). To avoid cross-contamination between samples, specific laboratory work areas were designated for the handling of reagents and samples and for the manipulation of amplified products. Positive and negative controls were included in all DNA extractions and PCR amplification reactions. No more than 15 serum samples were extracted at one time. In addition, water was subjected to the same steps of extraction and PCR amplification as a negative control for each group of five serum samples. HBV DNA positivity was confirmed by repeating the DNA extraction and amplification procedures.

Only samples that were positive in both independent assays were considered positive for HBV DNA. Restriction fragment length polymorfism (RFLP)-based genotyping was performed as described by Araujo et al. (2004) with some modifications (Motta-Castro et al. 2005). Nucleotide sequence analysis of the $S$ region was performed after semi-nested PCR amplification as previously reported (Motta-Castro et al. 2008).

The occult HBV infection prevalence and $95 \%$ confidence interval (CI) were calculated. The chi-square test was used to compare the frequencies of the HBV genotypes. A $p$ value $<0.05$ was defined as statistically significant. The data were analysed using Epi Info (CDC, Atlanta, GA, USA).

As shown in Table I, 31 of the 150 IDUs (20.6\%) had been exposed to HBV; one was HBsAg-positive, 18 were anti-HBc/anti-HBs reactive and 12 were positive only for anti-HBc. An additional nine IDUs $(6 \%)$ were positive only for anti-HBs, suggesting that these individuals had been vaccinated for HBV, but had not been exposed to the virus. The remaining IDUs $(n=110)$ were negative for HBV serological markers. HBV DNA was detected in the HBsAg-positive sample. Of the $149 \mathrm{HBsAg}$-negative samples, 19 were positive for HBV DNA, resulting in an occult HBV infection rate of $12.7 \%$ (95\% CI: 8.0-19.4); five of the 19 were anti-HBc/anti-HBs positive, one was positive for anti-HBc only and 13 were negative for HBV markers.

Table II presents the demographic characteristics, risk behaviours, co-infections and HBV genotypes of the IDUs with occult hepatitis B infections. All of these individuals were male and aged from 19-44 years. The duration of drug use among the participants ranged from five-29 years. All of these individuals reported several risk behaviours associated with the acquisition of HBV infections: sharing syringes and needles (13/19), sharing personal tools, such as razors, toothbrushes and nail clippers (5/19), tattoos (11/19), piercings (4/19), receiving blood transfusions (4/19), having multiple sexual partners (13/19) and a history of incarceration(10/19). Six IDUs were
TABLE I

Serological and hepatitis B virus (HBV) DNA status of 150 injecting drug users in Central-West Region of Brazil

\begin{tabular}{lcc}
\hline $\begin{array}{l}\text { Serological } \\
\text { markers }\end{array}$ & $\begin{array}{c}\text { HBV DNA } \\
\text { positive/total }\end{array}$ & $\%$ \\
\hline HBsAg & $1 / 1$ & 100 \\
Anti-HBc/anti-HBs & $5 / 18$ & 27.8 \\
Anti-HBc only & $1 / 12$ & 8.3 \\
Anti-HBs only & $0 / 9$ & 0 \\
No serological marker & $13 / 110$ & 11.8 \\
\hline
\end{tabular}

HBc: HBV core; HBs: HBV surface; HBsAg: HBs antigen.

co-infected with HCV (31.6\%) and one was HIV positive (5.3\%). All 19 HBV-DNA-positive, HBsAg-negative samples were successfully genotyped by RFLP, resulting in the identification of HBV genotypes $\mathrm{D}(\mathrm{n}=17,89.5 \%)$ and $\mathrm{A}(\mathrm{n}=2,10.5 \%)\left(\chi^{2}=23.68 ; \mathrm{p}=0.00\right)$. The HBsAgpositive IDU was infected with genotype D. Nucleotide sequencing of the $\mathrm{S}$ region was successfully performed for four of the $20 \mathrm{HBV}-\mathrm{DNA}$-positive samples. The results of the PCR-RFLP analysis were confirmed for these four samples, which included three from genotype $\mathrm{D}$ and one from genotype A.

The present study represents the first investigation designed to identify occult HBV infection in an IDU population in Brazil. No similar reports from Brazil were available for comparative purposes, but the prevalence of occult HBV infection measured in this study was higher than that observed in a population of non-IDUs in the Central-West Region of Brazil (2.7\%, CI 95\%: 0.7-8.3) (Ferreira et al. 2009). Nevertheless, the prevalence observed in this study is comparable to those observed in IDU populations Italy (3.2\%, CI 95\%: 0.5-12.1) (Vitale et al. 2008) and Argentina (7.7\%, CI 95\%: 3.9-14.0) (Trinks et al. 2008). It is, however, lower than those reported by Torbenson et al. (2004) and Lin et al. (2007) in Baltimore (45\%, CI 95\%: 37.6-52.5) and Taiwan (41.1\%, CI 95\%: 35.5-46.8), respectively. The patterns of local endemicity for HBV infection and the methodological differences between studies may explain the observed discrepancies in the rates of occult hepatitis B infection among populations. Furthermore, among certain patient groups, the prevalence of occult HBV infection would likely be significantly higher. For example, occult HBV infection has been observed in approximately $30-95 \%$ of chronic hepatitis C patients and in $8-51 \%$ of HIV patients (Hollinger \& Sood 2010, Said 2011). In the present study, 31.6\% of HBV DNA-positive individuals were also positive for anti-HCV and 5.2\% were positive for HIV. These findings were expected and can be explained by the shared risk factors associated with the transmission of these viruses.

IDUs constitute a population that is frequently exposed to various viral pathogens because they engage in high-risk sexual and injecting behaviours (Reimer et al. 2007, Nasir et al. 2011). Specifically, exposure to HBV as a consequence of sexual behaviours (multiple sexual part- 
TABLE II

Demographic characteristics, risk behaviours, co-infections and hepatitis B virus (HBV) genotypes from 19 injecting drug users (IDUs) with hepatitis B occult infection in Central-West Region of Brazil

\begin{tabular}{|c|c|c|c|c|c|}
\hline Sample & $\begin{array}{c}\text { Age } \\
\text { (years) }\end{array}$ & $\begin{array}{c}\text { Duration of drug use } \\
\text { (years) }\end{array}$ & $\begin{array}{c}\text { Risk } \\
\text { behaviours }\end{array}$ & Co-infections & $\begin{array}{c}\text { HBV } \\
\text { genotype }\end{array}$ \\
\hline IDU-1 & 24 & 10 & $\mathrm{a}, \mathrm{b}, \mathrm{c}, \mathrm{d}, \mathrm{g}$ & - & A \\
\hline IDU-2 & 19 & 5 & $\mathrm{a}, \mathrm{c}, \mathrm{f}, \mathrm{g}$ & - & $\mathrm{D}$ \\
\hline IDU-3 & 35 & 17 & $\mathrm{a}, \mathrm{f}, \mathrm{g}$ & - & $\mathrm{D}$ \\
\hline IDU-4 & 33 & 20 & $a, f$ & - & $\mathrm{D}$ \\
\hline IDU-5 & 27 & 11 & $\mathrm{a}, \mathrm{b}, \mathrm{c}, \mathrm{d}, \mathrm{g}$ & $\mathrm{HCV}$ & $\mathrm{D}$ \\
\hline IDU-6 & 35 & 9 & $\mathrm{c}, \mathrm{d}, \mathrm{f}, \mathrm{g}$ & - & A \\
\hline IDU-7 & 34 & 15 & $c, f, g$ & HIV & $\mathrm{D}$ \\
\hline IDU-8 & 40 & 26 & $\mathrm{a}, \mathrm{c}$ & $\mathrm{HCV}$ & $\mathrm{D}$ \\
\hline IDU-9 & 39 & 10 & $\mathrm{a}, \mathrm{f}$ & - & $\mathrm{D}$ \\
\hline IDU-10 & 27 & 12 & $\mathrm{c}, \mathrm{f}, \mathrm{g}$ & - & $\mathrm{D}$ \\
\hline IDU-11 & 34 & 18 & $a, b, f$ & $\mathrm{HCV}$ & $\mathrm{D}$ \\
\hline IDU-12 & 40 & 19 & $a, e, f, g$ & $\mathrm{HCV}$ & $\mathrm{D}$ \\
\hline IDU-13 & 27 & 12 & $e, f, g$ & - & $\mathrm{D}$ \\
\hline IDU-14 & 33 & 17 & $\mathrm{c}, \mathrm{f}, \mathrm{g}$ & $\mathrm{HCV}$ & $\mathrm{D}$ \\
\hline IDU-15 & 31 & 16 & $\mathrm{c}, \mathrm{d}, \mathrm{f}$ & - & $\mathrm{D}$ \\
\hline IDU-16 & 28 & 9 & $\mathrm{a}, \mathrm{b}$ & - & $\mathrm{D}$ \\
\hline IDU-17 & 25 & 6 & $\mathrm{a}, \mathrm{c}, \mathrm{e}$ & - & $\mathrm{D}$ \\
\hline IDU-18 & 44 & 29 & $\mathrm{a}, \mathrm{c}, \mathrm{e}, \mathrm{f}$ & - & $\mathrm{D}$ \\
\hline IDU-19 & 39 & 15 & $a, b$ & $\mathrm{HCV}$ & $\mathrm{D}$ \\
\hline
\end{tabular}

a: sharing syringes/needles; b: sharing personal tools; c: tattoo; d: piercing; e: blood transfusion; f: multiple sexual partners; g: incarceration; HCV: hepatitis C virus; HIV: human immunodeficiency virus. All individuals are male.

ners, 68.4\%) and parenteral behaviours (sharing syringes/needles, 68.4\% and tattooing, 57.9\%) were identified among IDUs with occult HBV infections. Additionally, secondary risk factors, such as a history of incarceration, should also be considered (Maher et al. 2004, Coelho et al. 2009). Another important characteristic was a longer period of drug use. For example, Lin et al. (2007) demonstrated that extended periods of drug use were associated with HBV infection in an IDU population. In the present study, most HBV-DNA-positive individuals had used injecting drugs for more than 10 years, which reflects the effects associated with cumulative exposures.

We found a predominance of genotype D in the IDU population studied and genotype A was the second most common. Interestingly, Panessa et al. (2009) previously identified a significant association between genotype D and injecting drug use. Moreover, the predominance of genotype D observed in IDUs in this study was consistent with findings reported elsewhere (Lindh et al. 2000, Swenson et al. 2001, Garfein et al. 2004, Alam et al. 2007, Alzahrani et al. 2009). However, additional studies will be needed to confirm these associations.

In conclusion, this study identified a high prevalence of occult HBV infection and the predominance of genotype D in an IDU population in the Central-West Region of Brazil. Because these individuals are potential sources of HBV transmission and because they reported sexual and/or parenteral risk factors associated with HBV infection, our findings suggest that additional attention should be given to the prevention of HBV transmission among IDUs in Brazil.

\section{ACKNOWLEDGEMENTS}

To Laura Branquinho do Nascimento, Thaís Augusto Marinho, Viviane Rodrigues Tavares and Nara Rúbia de Freitas, for their assistance during the collection of the blood samples, to Ágabo Macedo Costa e Silva and Nádia Rúbia da Silva Reis, for their technical assistance, and to the drug treatment centres and the injection drug users who participated in this study.

\section{REFERENCES}

Alam MM, Zaidi SZ, Shaukat S, Salmaan S, Angez M, Naeem A, Saleha S, Butt JA, Malik SA 2007. Common genotypes of hepatitis B virus prevalent in injecting drug abusers (addicts) of North West Frontier Province of Pakistan. Virol J 4: 63.

Alter MJ 2003. Epidemiology and prevention of hepatitis B. Semin Liver Dis 23: 39-46.

Alzahrani AJ, Dela Cruz DM, Obeid OE,Bukhari HA, Al-Qahtani AA, Al-Ahdal MN 2009. Molecular detection of hepatitis B, hepatitis $\mathrm{C}$ and torque teno viruses in drug users in Saudi Arabia. J Med Virol 81: 1343-1347.

Araujo NM, Mello FC, Yoshida CF, Niel C, Gomes SA 2004. High proportion of subgroup A' (genotype A) among Brazilian isolates of hepatitis B virus. Arch Virol 149: 1383-1395.

Brechot C, Kremsdorf D, Soussan P, Pineau P, Dejean A, PaterliniBrechot P, Tiollais P 2010. Hepatitis B virus (HBV)-related he- 
patocellular carcinoma (HCC): molecular mechanisms and novel paradigms. Pathol Biol 58: 278-287.

Coelho HC, Oliveira SAN, Miguel JC, Oliveira MLA, Figueiredo JFC, Perdoná GC, Passos ADC 2009. Soroprevalência da infecção pelo vírus da hepatite B em uma prisão brasileira. Rev Bras Epidemiol 12: 124-131.

Ferreira RC, Rodrigues FP, Teles SA, Lopes CL, Motta-Castro AR, Novais AC, Souto FJ, Martins RM 2009. Prevalence of hepatitis $\mathrm{B}$ virus and risk factors in Brazilian non-injecting drug users. J Med Virol 81: 602-609.

Garfein RS, Bower WA, Loney CM, Hutin YJ, Xia GL, Jawanda J, Groom AV, Nainan OV, Murphy JS, Bell BP 2004. Factors associated with fulminant liver failure during an outbreak among injection drug users with acute hepatitis B. Hepatology 40: 865-873.

Hollinger FB, Sood G 2010. Occult hepatitis B virus infection: a covert operation. $J$ Viral Hepat 17: 1-15.

Kurbanov F, Tanaka Y, Mizokami M 2010. Geographical and genetic diversity of the human hepatitis B virus. Hepatol Res 40: 14-30.

Liaw YF, Chu CM 2009. Hepatitis B virus infection. Lancet 373: $582-592$.

Lin CL, Liu CJ, Chen PJ, Lai MY, Chen DS, Kao JH 2007. High prevalence of occult hepatitis b virus infection in Taiwanese intravenous drug users. J Med Virol 79: 1674-1678.

Lindh M, Horal P, Norkrans G 2000. Acute hepatitis B in Western Sweden-genotypes and transmission routes. Infection 28: 161-163.

Lugoboni F, Quaglio G, Civitelli P, Mezzelani P 2009. Bloodborne viral hepatitis infections among drug users: the role of vaccination. Int J Environ Res Public Health 6: 400-413.

Maher L, Chant K, Jalaludin B, Sargent P 2004. Risk behaviors and antibody hepatitis B and $\mathrm{C}$ prevalence among injecting drug users in south-western Sydney, Australia. J Gastroenterol Hepatol 19: $1114-1120$.

Mello FC, Souto FJ, Nabuco LC, Villela-Nogueira CA, Coelho HS, Franz HC, Saraiva JC, Virgolino HA, Motta-Castro AR, Melo MM, Martins RM, Gomes SA 2007. Hepatitis B virus genotypes circulating in Brazil: molecular characterization of genotype $\mathrm{F}$ isolates. BMC Microbiol 23: 103.

Motta-Castro AR, Martins RM, Araujo NM, Niel C, Facholi GB, Lago BV, Mello FC, Gomes SA 2008. Molecular epidemiology of hepatitis B virus in an isolated Afro-Brazilian community. Arch Virol 153: 2197-2205.
Motta-Castro ARC, Martins RMB, Yoshida CFT, Teles SA, Paniago AM, Lima KMB, Gomes SA 2005. Hepatitis B virus infection in isolated Afro-Brazilian communities. J Med Virol 77: 188-193.

Nasir A, Todd CS, Stanekzai MR, Bautista CT, Botros BA, Scott PT, Strathdee SA, Tjaden J 2011. Prevalence of HIV, hepatitis B and hepatitis $\mathrm{C}$ and associated risk behaviours amongst injecting drug users in three Afghan cities. Int J Drug Policy 22: 145-152.

Niel C, Moraes MTB, Gaspar AMC, Yoshida CFT, Gomes SA 1994. Genetic diversity of hepatitis B virus strains isolated in Rio de Janeiro, Brazil. J Med Virol 44: 180-186.

Panessa C, Hill WD, Giles E, Yu A, Harvard S, Butt G, Andonov A, Krajden M, Osiowy C 2009. Genotype D amongst injection drug users with acute hepatitis B virus infection in British Columbia. $J$ Viral Hepat 16: 64-73.

Raimondo G, Pollicino T, Cacciola I, Squadrito G 2007. Occult hepatitis B virus infection. $J$ Hepatol 46: 160-170.

Reimer J, Lorenzen J, Baetz B, Fischer B, Rehm J, Haasen C, Backmund M 2007. Multiple viral hepatitis in injection drug users and associated risk factors. $J$ Gastroenterol Hepatol 22: 80-85.

Said ZNA 2011. An overview of occult hepatitis B virus infection. World J Gastroenterol 17: 1927-1938.

Swenson PD, Van Geyt C, Alexander ER, Hagan H, Freitag-Koontz JM, Wilson S, Norder H, Magnius LO, Stuyver L 2001. Hepatitis B virus genotypes and HBsAg subtypes in refugees and injection drug users in the United States determined by LiPA and monoclonal EIA. J Med Virol 64: 305-311.

Torbenson M, Kannangai R, Astemborski J, Strathdee SA, Vlahov D, Thomas DL 2004. High prevalence of occult hepatitis B in Baltimore injection drug users. Hepatology 239: 51-57.

Trinks J, Cuestas ML, Tanaka Y, Mathet VL, Minassian ML, Rivero CW, Benetucci JA, Gímenez ED, Segura M, Bobillo MC, Corach D, Ghiringhelli PD, Sánchez DO, Avila MM, Peralta LA, Kurbanov F, Weissenbacher MC, Simmonds P, Mizokami M, Oubiña JR 2008. Two simultaneous hepatitis B virus epidemics among injecting drug users and men who have sex with men in Buenos Aires, Argentina: characterization of the first D/A recombinant from the American continent. J Viral Hepat 15: 827-838.

Vitale F, Tramuto F, Orlando A, Vizzini G, Meli V, Cerame G, Mazzucco W, Virdone R, Palazzo U, Villafrate MR, Tagger A, Romano N 2008. Can the serological status of anti-HBc alone be considered a sentinel marker for detection of occult HBV infection? J Med Virol 80: 577-582. 